\title{
THE ECONOMIC-POLITICAL IMPORTANCE OF HYDROCARBONS IN CASE OF THE ACTUALITY OF DEVELOPIING OF RENEWABLE RESOURCES
}

\author{
KHATUNA TABAGARI \\ Doctor of Economics, Researcher \\ The Institute for the Research of Economic \\ and Social Problems of Globalization, \\ European University, Georgia \\ tabagarikhatuna@gmail.com
}

Abstract. Oil and natural gas are significant commodities in the world, on which the world industry, production, transport and other directions are depended. After the spreading of Corona Virus and continuous oil production by Russia, oil price began decreasing. This fact impacted on economy of the world oil producer countries and not only.

It is noteworthy that the total bulk of the world oil reserves were 244.1 billion tonnes in 2018 which was increased by $1.3 \%$ compared to last year. At the same year the oil consumption was 4.5 billion tonnes which was increased by $1.6 \%$ compared to last year, too. Though oil consumption is connected to an ecological problems. The situation is lighter in case of natural gas, than oil.

The alternative energies of oil, and generally hydrocarbons, are considered green economy, namely renewable energy resources. This means rationally using the resources, keeping reproductive processes, increasing productivity, saving economic and social prosperity of humans. Replacing non-renewable, lacking energy resources are being replaced with the renewable and ecologically clear ones (Abesadze, R. 2019).

The aim of the sudy is to investigate how it is possible to replace hydrocarbons with renawble resources, how it only depends on the cost and stability of them, how it is possible to "let" the green economy, namely, renewable resources to be developed in the world, when oil and natural gas represent one of the instruments of power in the context of globalization.

\section{KEYWORDS: CORONAVIRUS, FORECASTING, COMPARTMENTAL MODELS, RICHARDS MODEL, POLYNOMIAL MODEL, NEURAL} NETWORK MODEL, BASIC REPRODUCTION NUMBER.

For citation: Tabagari, Kh., (2020). The Economic-political importance of hydrocarbons in case of the actuality of developing of renewable resources. Globalization and Business, 10. 243-247. https://doi.org/10.35945/gb.2020.10.031

\section{INTRODUCTION \\ Economic-Political Review of Oil and Natural Gas}

In 2018 the amount of oil consumption was $58 \%$ of total energy consumption in 2018 ( $24 \%$ of natural gas, 34\% - oil). Oil consumption in transport sector was $70 \%$, in industry $24 \%$ and in other sectors $6 \%$ of total oil consumption of US, and as for natural gas consumption in electricity was $34.65 \%$, in industry $-33.66 \%$ and in other sectors $-31.69 \%{ }^{1}$ of total gas consumption of US (BP Statistical review of world energy, 2019) (U.S. Energy Information Administration, 2018).

Along both its energy importance, oil and natural gas also have political implication. Hydrocarbon's reserves, production, consumption and transit represent one of the vital aspects for security of the countries, their economy and policy (Tvalchrelidze et al., 2016) (Tvalchrelidze, A. G. and Kervalishvili, P. J., 2019). Two laws impact on oil price: All

\footnotetext{
Author's note - The data of world oil consumption in different sectors are not matched, so we used the US example.
}

commodity prices depend on oil price, oil price is set in US dollar, and this means that oil price depends on US exchange rate. Three factors influence on the role of oil: It is one of the most required energy resources in 2018, oil price determines fuel price and oil price indirectly impacts on commodity price at commodity exchange market (Tvalchrelidze et al., 2016) (BP Statistical review of world energy, 2019). According to figure 1, all significant dates which influenced on oil price are given. For instance, there can be distinguished several dates of them: in 1869 withdrawal of the Suez Canal, in 1947 oil deficit in US, in 1960 establishing of OPEC (Organization of Petroleum Exporting Countries), in 1973 oil crisis, in 1974 establishing of IEA (International Energy Agency), in 1979 Iran revolution, here must be highlighted in 2008 GeorgiaRussia war - when Russia tried to bomb Baku-Tbilisi-Ceyhan oil pipeline as its aim was to interrupt transit oil towards Europe and so on (Yergin, D., 1993) (United States Cruptologic History, 1998) (Organization of the Petroleum Exporting Countries - OPEC, 2020) (Margvelashvili et al., 2019). 


\section{Discussion}

The Role of Hydrocarbon in the Modern World

Spreading of the virus negatively impacted on the world economy, oil price, wchich caused the reduction of oil consumption, the oil price sharply began decreasing since April, 2020, that resulted negative changes of incomes and oil exports in oil producer countries (Mulder, N., Tooze, A., 2020) (Trading Economics, Crude Oil, 2020). Disagreements between Russia and Saudi Arabia about the oil production also negatively impacted on oil price, too: Russia refused the offer of Saudi Arabia to decrease the oil production with million barrels per day (approximately 136.99 thousand tonnes of oil) in oil market at OPEC+ meeting; OPEC+ means the unification of OPEC member and non-member countries to regulate oil market problems (Cook, S. A., 2020) (BP Statistical review of world energy, 2019). That resulted the abundance of oil supply on oil market, Saudi Arabia decided to continue oil production which finally caused oil price reduction (Trading Economics, Crude Oil, 2020).
The significance of oil is still vital in economy, politics and energy sector.

Natural gas also represents an important energy resource in the world. Basically, 2006-2007 and 2009 conflicts refer to gas. Russia, as a rich country with natural gas reserves, tries to use it for its own political-economic aims and impact on Ukraine, EU member and non-member countries with the increasing and decreasing the natural gas production. An obvious example of this refers a laying the gas pipeline of Nord Stream 2 towards Germany in 2013 to avoid gas transits through Ukraine to supply it to EU. So it means that after 2017 Ukraine is no longer a transitional country of Russian energy resource (Nutu et al., 2019) (Pavlenko et al., 019).

Oil and natural gas are very important energy resources for most of the countries, as we have already mentioned them in case of US and, as a result, their economy is significantly depended on them. Replacing hydrocarbons with renewable energy resources are connected to time and technological changes (see fig.: 2, 3).

Figure 1. Oil price in 1970-2018

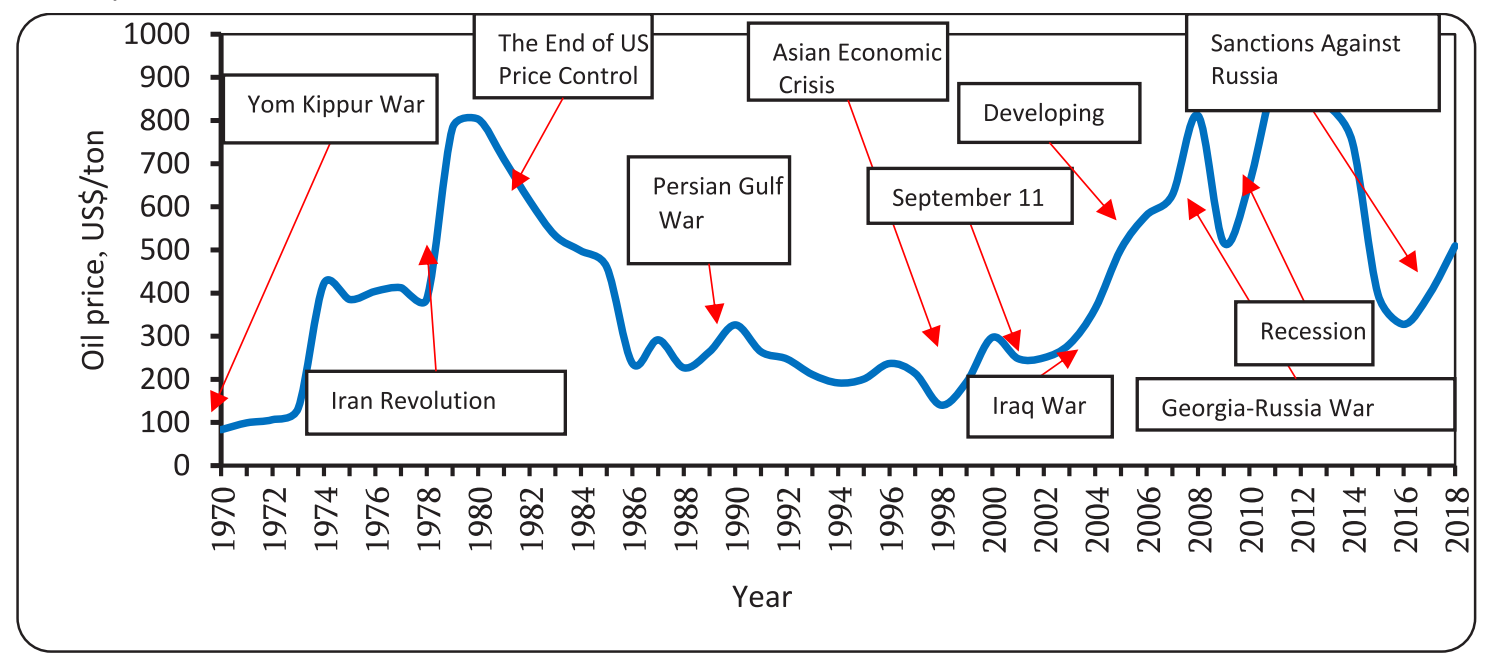

Source: BP Statistical review of world energy, 2019

Figure 2. Top oil consumer countries in 2018 (world oil consumption - $4477 \mathrm{mln}$ tonnes)

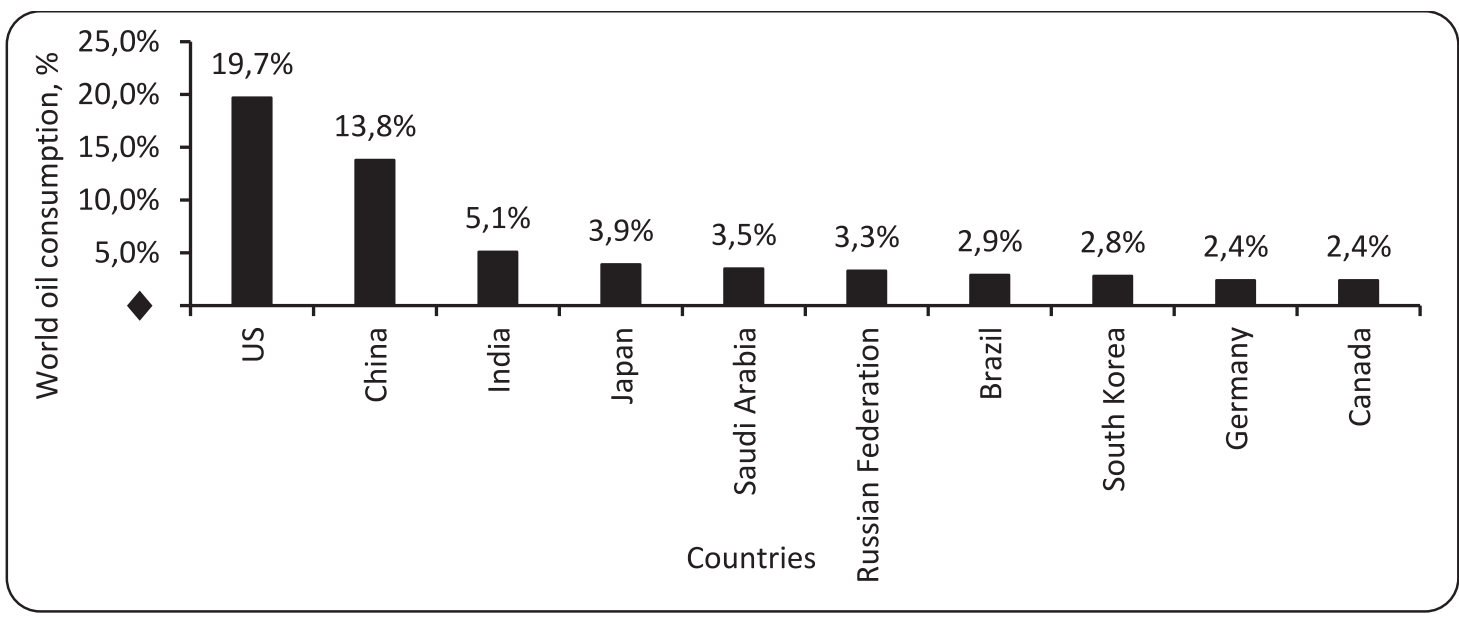

Source: BP Statistical review of world energy, 2019 
Figure 3. Top natural gas consumer countries in 2018 (world natural gas consumption - 3309 million tonnes of oil equivalent)

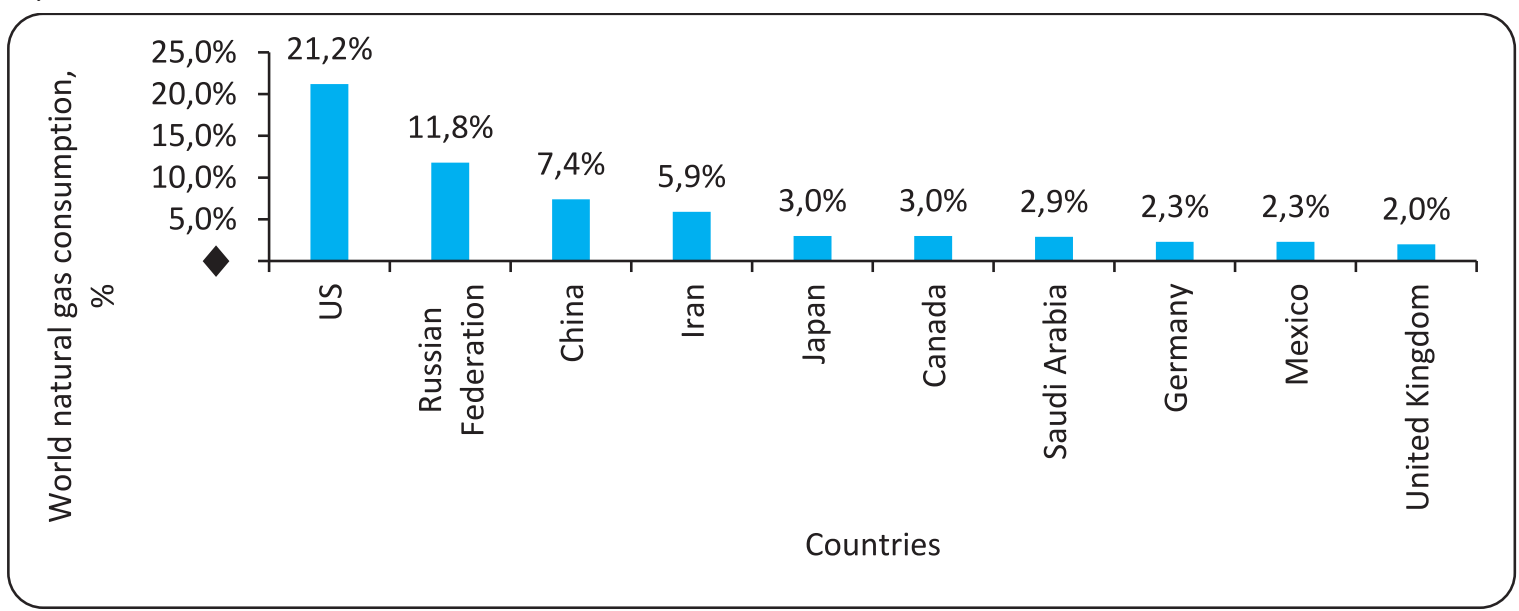

Source: BP Statistical review of world energy, 2019

\section{World Consumption of Renewable energy resources}

Renewable energy resources are significant part of the green economy (Abesadze, R., 2019). The world energy development enters into a new historical era, when clear and low carbon energy are more required. It's important for US to be less dependent on hydrocarbons, for this purpose 40 year's US dream came true in 2008 when its government put forward a proposal about "Green energy transition of US". It meant that using shelf oil and natural gas, new approaching - continuous reservation of oil and natural gas, innovative methods in the process of production and etc. As for China, on the one hand, it tries to decrease the energy consumption and, on the other hand, diversify system of energy supplement, make revolution of energy technology to improve industry and so on (Zou, C., Zhao, Q., Zhang, G., Ziong, B., 2016). Despite this fact, according to the official statistical data, the abovementioned countries are still active oil and natural gas consumers (BP Statistical review of world energy, 2019).
According to the right official statistical data, the amount of renewable energy consumption will begin increasing after 2020, but till 2040 its consumption will reach approximately a half of future gas and oil consumptions (see fig.: 4).

According to the official statistical data, hydroresources are most consumed energy resources among the renewable energy resources. Its basical consumer countries are China, US, Russia and etc., though the load of their consumed energy did not exceed $10 \%$ of their total energy consumption, except for China. But there is worse situtation of the consumoption of the rest of the renewable energy resources: these ones also did not exceed $10 \%$ of their total energy consumption, except for Germany (see tab.:1, 2) (BP Statistical review of world energy, 2019).

\section{CONCLUSIONS}

In conclusion, we can say that at least until 2040:

- The importance of oil and gas consumption will take a bigger place in the world energy consumption than renewable energy resources;

Figure 4. Different source of energy consumption in 1970-2040

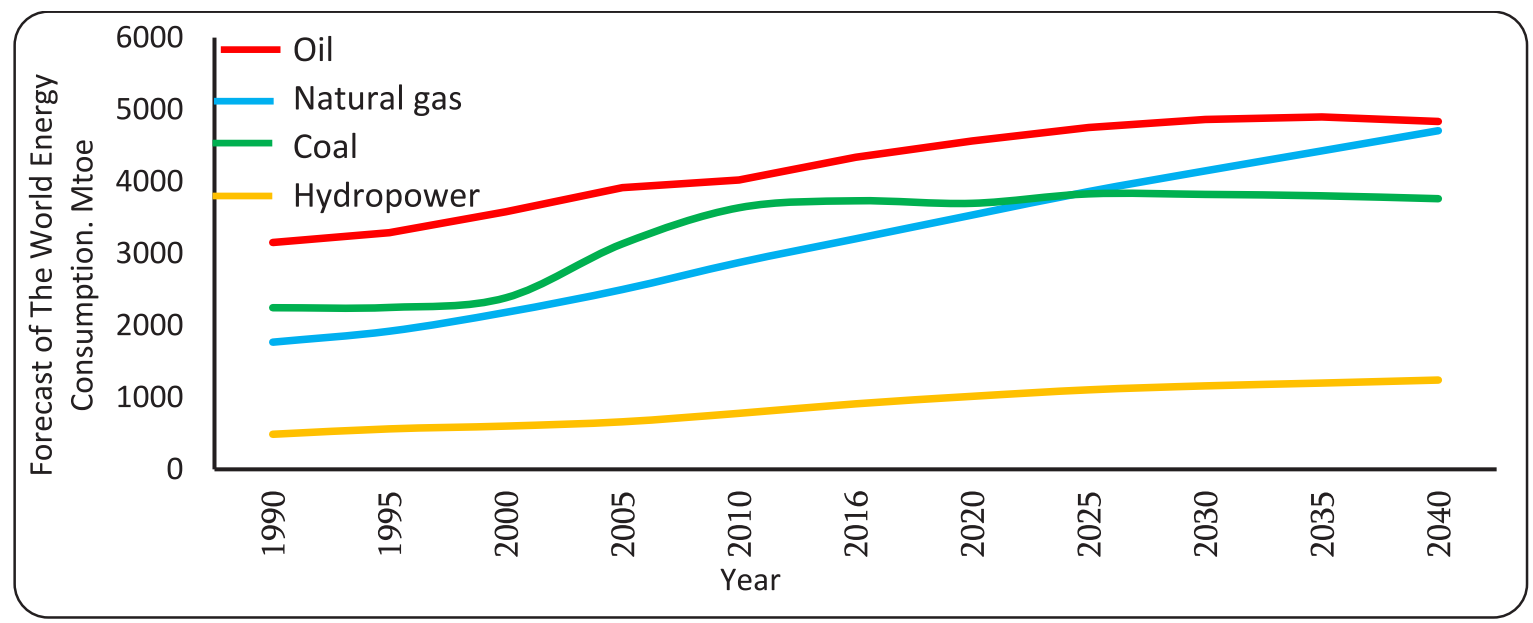

Source: BP Energy Outlook, 2019; BP Statistical review of world energy, 2019 
Table 1. The share (\%) of consumed hydro resources of total energy consumption by top hydropower energy consumer countries in 2005, 2010, 2015 and 2018

\begin{tabular}{|l|l|l|l|l|l|}
\hline № & Countries & 2005 & 2010 & 2015 & 2018 \\
\hline 1 & China & 13.6 & 20.8 & 28.6 & 28.7 \\
\hline 2 & US & 9.3 & 7.6 & 6.4 & 9.2 \\
\hline 3 & Russia & 6.0 & 4.9 & 4.3 & 4.5 \\
\hline 4 & India & 3.3 & 3.2 & 3.1 & 3.3 \\
\hline 5 & Japan & 2.7 & 2.6 & 2.5 & 1.9 \\
\hline & Total (Mtoe) & 661.4 & 784.2 & 892.3 & 948.8 \\
\hline
\end{tabular}

Source: BP Statistical review of world energy, 2016; BP Statistical review of world energy, 2019

Table 2. The share (\%) of consumed renewable energy resources of total energy consumption by top renewable energy consumer countries in 2005, 2010, 2015 and 2018

\begin{tabular}{|c|c|c|c|c|c|}
\hline № & Countries & 20056. & 20106. & 20156. & 20186. \\
\hline 1 & US & 24.9 & 27.3 & 19.6 & 18.5 \\
\hline 2 & Germany & 11.7 & 13.2 & 11.0 & 8.4 \\
\hline 3 & Japan & 7.8 & 4.7 & 4.0 & 4.5 \\
\hline 4 & India & 2.8 & 4.4 & 4.2 & 4.9 \\
\hline \multirow[t]{2}{*}{5} & China & 2.0 & 7.6 & 17.2 & 25.6 \\
\hline & Total (Mtoe) & 83.2 & 144.2 & 364.9 & 561 \\
\hline
\end{tabular}

Source: BP Statistical review of world energy, 2016; BP Statistical review of world energy, 2019

- Hydrocarbons' reserves, productions, consumptions and transits, as one of the power instruments, will be connected to the political and economic aspects;

- Renewable energy resources as significant factors for ecological environment can be developed in the very countries which are less hydrocarbons consumer ones or rich with renewable energy resources;

- According to the official statistical data, renewable energy resources will be about a half of the forecasted gas and oil consumption by the right 2040;
- If countries need to begin consumption of the renewable energy resources in industry, transport, electricity and other significant sectors, there must be installed new technology of energy creation. And this one is directly connected to time. In addition, if we assume that hydrocarbon resources are replaced with the renewable energy resources, there can be changed the rules of the world geopolitics and designed new reality and different countries with influences in the world policy and economy.

\section{REFERENCES}

Abesadze, R. (2019, June 17). «Green» Economy: Meaning and challenges. Ivane Javakhishvili Tbilisi State University, Paata Gugushvili Economic Institute http://conferenceconomics.tsu.ge/?mcat=1\&cat=pers\&leng=ge\&adgi=737\& title=\%20\%20\%E2\%80\%9E\%E1\%83\%9B\%E1\%83\%AC\%E1\%83\%95\%E1\%83\%90\%E1\%83\%9C\%E1\%83\%94\%E2\%80 \%9C\%20\%E1\%83\%94\%E1\%83\%99\%E1\%83\%9D\%E1\%83\%9C\%E1\%83\%9D\%E1\%83\%9B\%E1\%83\%98\%E1\%83\%99 \%Е1\%83\%90:\%20\%E1\%83\%90\%E1\%83\%

BP Energy Outlook. (2019). BP Energy Outlook. London: BP.

BP Statistical review of world energy. (2016). Statistical review of world energy. London: BP.

BP Statistical review of world energy. (2019). Statistical review of world energy. London: BP.

Cook, S. A. (2020, April 9). Foreign Policy. Retrieved from https://foreignpolicy.com/2020/04/09/russia-saudi-arabia-oil-pricewar-middle-east/ 
Margvelashvili, M., Mukhigulashvili, G., \& Kvaratskhelia, T. (2019). Georgia: Energy as Battleground with Russia. Washington: National Endowment for Democracy.

Mulder, N., \& Tooze, A. (2020). Foreign Policy. Retrieved from https://foreignpolicy.com/2020/04/23/the-coronavirus-oilshock-is-just-getting-started/

Nutu, A. O., \& Ionita, S. (2019). Introduction: How the Kremlin may enhance its energy leverage in the West and what should we learn from Central and Eastern Europe. National Endowment for Democracy.

Organization of the Petroleum Exporting Countries - OPEC. (2020). Retrieved from https://www.opec.org/opec_web/en/ about_us/24.htm

Pavlenko, O., Nitsovych, R., Nazarenko, D., Synytsia, A., \& Yaroshchuk, O. (2019). Ukraine: the costs of fighting gains of fighting for energy independence. Washington: National Endowment for Democracy.Trading Economics, Crude Oil. (2020). Retrieved from https://tradingeconomics.com/commodity/crude-oil

Tvalchrelidze, A. G. and Kervalishvili, P. J. (2019). Economic security of the Southern Caucasus: opportunities and challenges. Nanotechnology Perceptions, 21-47.

Tvalchrelidze, A., Berberashvili, T., Otarashvili, M. (2016). Commodity Economy (Role of Commodity in Globalized World). Tbilisi: Nekeri. (In Georgian)

U.S. Energy Information Administration. (2018). Retrieved from https://www.eia.gov/energyexplained/us-energy-facts/

United States Cruptologic History. (1998). The Suez Crisis: A brief History(U). Retrieved from https://www.nsa.gov/Portals/70/ documents/news-features/declassified-documents/cryp

Yergin, D. (1993). The Prize, the epic quest for oil, money \& power. New York: Free Press.

Zou, C., Zhao, Q., Zhang, G., \& Ziong, B. (2016, January). Energy revolution: From a fossil energy era to a new energy era. Natural Gas Industry B, 3(1), 1-11. 